\title{
FAILURE TESTS OF STEEL BEAMS WITH ECCENTRIC WEB OPENINGS
}

\section{By}

\section{S. ABD-RABOU}

Assist. Prof., Structural Eng. Depart. Mansoura University, EGYPT
Y. ABO MOSALLAM

Assist. Prof. , Production Eng. Depart., Mansoura University, EGYPT

\section{A. BADR}

Assoch. Prof., Structural Eng. Depart.

Mansoura University, EGYPT

$$
\begin{aligned}
& \text { إختيارات على الكرات العديدية ذات الفتحات العستطيلة المسدرية }
\end{aligned}
$$

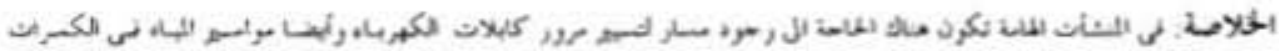

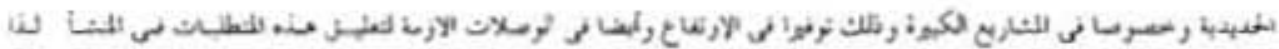

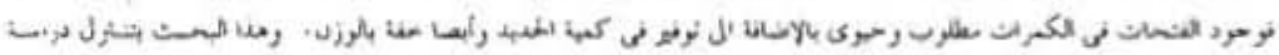

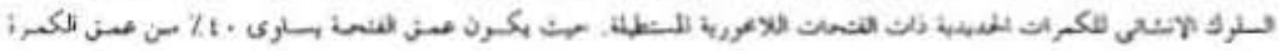

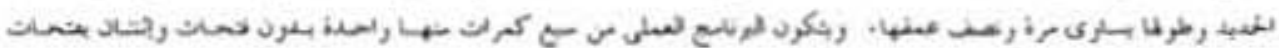

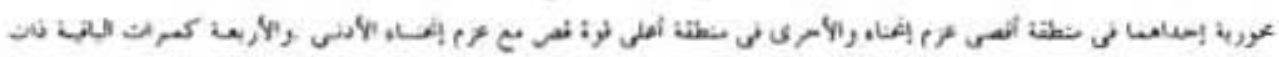

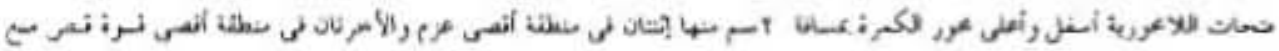

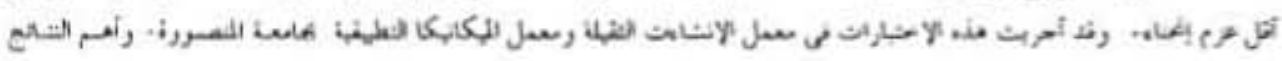

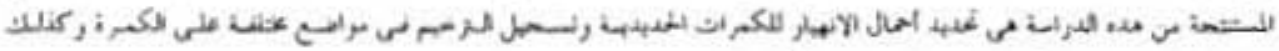

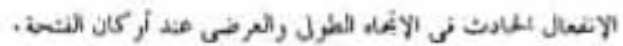

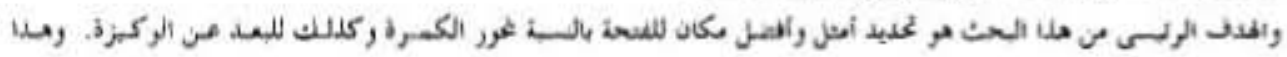

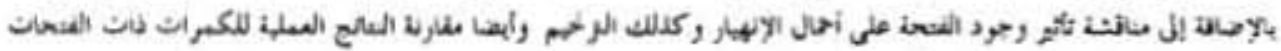

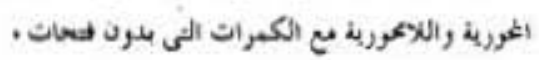

\section{ABSTRACT.}

An experimental investigation to study steel beams with eccentric web openings is presented. Four steel beams, with eccentric web openings: one beam without openings and two with centric openings were tested. IPE200 profile was used for the tested beams. The opening sizes were fixed and have depth equal to 40 percent of the steel beam depth and a length equal to one and half the opening depth. The opening locations were varied to investigate the structural behavior of these types of beams with openings. Web openings generally reduce the strength of steel beams. Beams under pure moment fail by yielding in the steel below the neutral axis. Beams under high shear-low moment straining actions fail by the formation of plastic hinges at 
under high shear-low moment straining actions fail by the formation of plastic hinges at the corners of the opening followed by yielding in the steel beam.

The main parameters in this study were the failure loads, the deflections at various locations on the span of the beam, the strains in longitudinal and transverse directions at the corners of the opening and the modes of failure.

The main objective of this investigation is to study experimentally the optimum location of the openings relative to the center line of the beam as well as relative to the support of the beam.

\section{1- INTRODUCTION.}

The demand for economical, efficient structures has led designers to reduce or eliminate the space below beams and girders in buildings provided for utility passage. The use of web openings (holes in the vertical portion of the steel sections) allows the passage of utilities through the beams, reduce the total depth of roof. The total height of the building can be reduced, resulting in a substantial reduction in material costs The plastic behavior and ultimate strength analysis for I-beam with rectangular openings which may be centered at mid-span of the beam have been reported [1] using the general theory of plastic collapse. The idealized stress distribution at the boundaries of the hole in the I-beam have been discussed [2,3]. A summary of some proposals for design methods as well as experimental investigations for I-beams with opening have been presented $[4,5 \& 6]$.

The present paper presents the results of an experimental investigation designed to study the behavior of steel beams with eccentric rectangular web openings Testing methods are outlines, beam behavior is described in detail, and major observations are summarized. There are two cases for the location of the web openings in the tested beams. Case(A), the position of the opening is located in the high shearlow moment region while case (B), the position of the web opening is located in the region of pure moment

A comparison between the experimental results for the tested beams with and without web openings is discussed. The experimental program has been executed in the Heavy Structures and Applied Mechanics Laboratories, at Mansoura university.

\section{2 - EXPERIMENTAL INVESTIGATION.}

The aim from this experimental investigation is to find the optimum location of the web opening reiative to the high shear-low moment and the pure moment regains (cases $A \& B$ ) and the opening positions (centric or top and bottom eccentric). For the six beams tested, two different centric opening locations were used and the other were eccentric opening locations.

In both the eccentric opening and the centric opening steel beams the same steel section was used and both have the same moment-shear ratio at the opening. The web openings were rectangular centric and eccentric with respect to the centriod of the steel section. (Fig.1). Opening sizes were fixed with a depth equal to $40 \%$ of the steel beam depth and a length equal to one and half the opening depth as shown in Fig. 1 . 


\section{1 : Beam design.}

The design of the seven steel beams followed the Egyptian Code [7]. However, since the beams were to be loaded to failure, the ultimate strength design methods [3\&4] were used. The opening locations, load configurations, and the span lengths for the beams are shown in Fig. 1. Also, in this figure, pairs of bearing stiffeners and bearing plates were provided for the steel beam at the supports and at the loading points.

\section{2 : Beam Fabrication.}

The steel beams were purchased from a structural steel factory to determine the mechanical properties of the steel material Six specimens (three from web and three from flange) have been taken according to German Specifications [8]. From the tensile tests for these specimens, the yield and uitimate stresses were 2.94 and $4.08 \mathrm{~V} / \mathrm{cm}^{2}$ respectively. Double flat stiffeners were weided inclose contact to the web and flange of the steel beams

Eight $\mathrm{mm}$ diameter holes were driled at the comers of the web openings to reduce stress concentrations (Fig. 1). The openungs were formed using a drilling machine and angular and arch files. Grinding of the cut surfaces was restricted to the strain gages locations. The beams were tested in the main steel frame in the Heavy Structural Laboratory. A pin and a roller were used to provide the simple supports. Both supports consist of $54 \mathrm{~mm}$ diameter cold rolled bars

\section{3 : Instrumentations.}

Each of the six beams was provided with electrical resistance strain gages placed at the comers of the opening to measure the strains in the longitudinal and transverse directions at the corners of the holes. The gages were recessed $15 \mathrm{~mm}$ from the edges of the opening to avoid regions of stress concentration. The steei surfaces were ground to remove scale and surface imperfections. Foil strain gages with resistance $120 \mathrm{Ohm}$ and $10 \mathrm{~mm}$ gage length were used. The gages were glued to the steel at the corners. Dial gages, graduated in $0.01 \mathrm{~mm}$, were used to measure vertical deflection.

The loads were applied as two concentrated loads at third points of the span in equal increments of ( $300 \mathrm{~kg}$ ) using a digital pressure device till failure (Fig. 2). At each step of loading, the vertical deflection at vanous locations on the span and the strains in the longitudinal and transverse directions at the comers of the opening were recorded

\section{3 : DISCUSSIONS \& ANALYSIS.}

According to the experimental results, the behavior of the tested beams is discussed with respect to deflections at various locations. longitudinal and transverse strains at comers of the opening, failure loads and load-deflection and load-strain relationships. 


\section{3-1-1: Combined Strains at the corners of the Opening.}

Figure 3 shows the distribution of the combined strains at the corners of the opening in pure moment and high shear-low moment regions (cases A\&B) respectively From this figure, the mode of failure can be expected at any step of the loading test. It can also predict the sequence of formation of the plastic hinges at the corners of the opening. For example, from case (B), it can be concluded that the sequence of formation of the plastic hinges will be at corners $3,1,2$, and 4 respectively.

Also, it can be noticed that the values of the combined strains for beams $\left(\mathrm{B}_{3 \mathrm{U}}\right)$ and $\left(B_{5 C}\right)$ are higher than those for beams $\left(B_{2} c \& B_{4 L}\right)$ and $\left(B_{6} \& \& B_{7}\right)$ respectively. Moreover, the expected modes of failure are in good agreement with the modes of failures in that occurred in the tested beams as shown in Figs 3\&9.

\section{3-1-2 : Load-Strain Relationship.}

The relations between the load and longitudinal and transverse strains at corners $(1,2.3 \& 4)$ of the opening till failure are shown in Figs.4\&5 for tested beams $\left(\mathrm{B}_{2} \mathrm{~B}_{3} \cup \& \mathrm{~B}_{4 \mathrm{~L}}\right)$ and $\left(\mathrm{B}_{5 \mathrm{C}}, \mathrm{B}_{6} \cup \& \mathrm{~B}_{\pi}\right)$ respectively

From Fig.4, it is noticed that the longitudinal and transverse strains at the corners of the opening in case (A) are highly affected by the position of the opening (centric, top or bottom eccentricity). The sign of the strains at corner 3 changed from negative to positive due to the change of the position of the opening from centric to bottom eccentric. The sign of the strains at corners 1,2 and 4 was constant but took different values due to the change in the opening position. Also, the values of strains, where the opening was at top eccentricity were smaller than those for other positions of the opening (centric and bottom eccentricity).

From Fig 5, it is noticed that, the values of the strains for the opening in pure moment region (case B), were very small and can be neglected for ratios of ( $\left.\mathrm{P} / \mathrm{P}_{\text {Fallure }}\right)$ ranging from 0.0 to 0.83 . These values are not affected by the position of the opening (centric, top or bottom eccentric). Also, the values of the stains at the comers in high shear -low moment region (case A) were higher than the corresponding values for the opening location in pure moment (case B).

\section{2 : Deflections.}

The measured deflections along the span of the tested beams for different positions of the openings are given in table (1) and are shown in Fig.6. It is noticed from this table as well as this figure the following remarks

(i) The maximum recorded deflection along the beam was in the beam with centric opening $\left(B_{2} C\right)$ in case of high shear-low moment region (case $A$ ) while the minimum recorded deflection was in the beam with top eccentric opening $\left(B_{3}\right)$ in case of high shear-low moment region.

(ii) The maximum recorded deflection along the beam was in the beam with bottom eccentric opening $\left(\mathrm{B}_{71}\right)$ in case of pure moment region (case $\mathrm{B}$ ) while the minimum recorded deflection along the beam was in the beam with top eccentric opening $\left(\mathrm{B}_{6 \mathrm{U}}\right)$ in pure moment region. 
Mansoura Engineering Journal (MEJ), Vol.20, No.3, Sept.1995 C.5

Table (1) : Deflection values in mm. at a load ( $34.5 \mathrm{t})$ along the span of the different tested beams.

\begin{tabular}{|c|c|c|c|c|c|c|c|c|c|c|}
\hline \multicolumn{11}{|c|}{ Opening Location } \\
\hline \multirow[b]{2}{*}{ Opening position } & \multicolumn{5}{|c|}{ Case (A) Hight shear - Low moment region } & \multicolumn{5}{|c|}{ Case (B). Pure moment region } \\
\hline & $1^{*}$ & $2^{*}$ & $3^{*}$ & $4^{*}$ & $5 *$ & $1^{*}$ & $2^{*}$ & $3 *$ & $4^{*}$ & $5^{*}$ \\
\hline Without opening & $\ldots$ & $\ldots$ & 6.44 & 7.17 & 6.6 & 644 & $\ldots$ & 7.17 & $\ldots . . .$. & 6.6 \\
\hline Centric opening & 5.64 & 13.04 & 17.14 & 15.4 & 12.84 & 768 & 8.60 & 8.45 & 8.45 & 7.47 \\
\hline Top eccentric & 4.57 & 5.65 & 12.42 & 11.66 & 9.65 & 9.65 & 11.37 & 12.62 & 11.4 & 9.71 \\
\hline Boitom eccentric & 4.74 & 13.62 & 15.31 & 14.41 & 7.76 & 13.58 & 16.06 & 16.15 & 16.1 & 13.74 \\
\hline
\end{tabular}

\subsection{1 : Load-Deflection Relationship.}

The load deflection curves for the tested beams with and without web openings for different opening locations till failure are shown in Figs. 7a, $7 \mathrm{~b} \& 8$. It is noticed from Fig. 7a that the load capacity of solid beam $\left(B_{1 S}\right)$ is higher than of perforated beams $\left(\mathrm{B}_{2 \mathrm{C}}, \mathrm{B}_{3 \mathrm{U}}, \mathrm{B}_{4 \mathrm{~L}}\right.$ \& $\left.\mathrm{B}_{5 \mathrm{C}}, \mathrm{B}_{6 \mathrm{U}}, \mathrm{B}_{7 \mathrm{U}}\right)$. The load capacities of beams $\left(\mathrm{B}_{5 \mathrm{C}}, \mathrm{B}_{6 \mathrm{U}}\right.$ \& $\left.\mathrm{B}_{7 \mathrm{~L}}\right)$ with opening in pure moment region are greater than those of beams $\left(B_{2} C_{3} B_{3 U} \& B_{4 L}\right)$ with opening under the combined action of shear and moment. The recorded deflections at different positions $(1,2,3,4 \& 5)$ on the span of the tested beams are given in Figs. $7 a \& 8$ From these figures, it is noticed that the effect of the opening on the deflections of beams with opening in high shear-low moment region (case A) is higher than for the beams with opening in pure moment region (case B)

\section{3: Failure Loads.}

The failure loads for beams $\left(\mathrm{B}_{2} \mathrm{C}, \mathrm{B}_{3} \mathrm{U} \& \mathrm{~B}_{4 \mathrm{~L}}\right)$ with opening in high shear-low moment region and $\left(\mathrm{B}_{5 \mathrm{C}}, \mathrm{B}_{6 \mathrm{U}} \& \mathrm{~B}_{7 \mathrm{~L}}\right)$ in pure moment region have decreased by ratios $5.3 \%, 6.1 \%$ \& $7.6 \%$ and $6.8 \%, 2.3 \%$ \& $5.3 \%$ than the failure load of beam $\left(B_{15}\right)$ without opening respectively. The modes of failure were the formation of the plastic hinges at the corners of the opening for beams $\left(B_{2} C, B_{3} \cup \& B_{4}\right)$ and yielding in the flanges for beams $\left(\mathrm{B}_{1 \mathrm{~S}}, \mathrm{~B}_{S \mathrm{C}}, \mathrm{B}_{6 \mathrm{U}}\right.$ \& $\left.\mathrm{B}_{7 L}\right)$

\section{4: CONCLUSIONS.}

From the experimental results of the tested beams with centric and eccentric opening in cases of high shear-low moment and pure moment regions, the following conclusions are drawn :

1: The top eccentric opening in beams with holes is the optimum position when the opening is in the high shear-low moment region.

2: The centric opening in beams with holes is the optimum position when the opening is in the pure moment region.

3: The load capacity of a beam with opening in pure moment region is greater than the corresponding value for a beam with opening in combined shear-moment region 


\section{6 ABD-RABOU, ABO MOSALLAM \& BADR}

4. The values of strains in the longitudinal and transverse directions at the comers of the opening in case of beams with openings in pure moment region were very small and can be neglected in the range of the ratio $\left(\mathrm{P} / \mathrm{P}_{\text {Failure }}\right)$ from 0.0 to 0.8

5: The strains at the corners of the opening in case of beams with openings in high shear-low moment region were highly affected by the position of opening. They have high and different values for different positions of the opening (centric, top \& bottom eccentric).

6: The maximum recorded deflection along the beam was in the beam with centric opening in case of high shear-low moment region while the minimum recorded deflection was in the beam with top eccentric opening in case of high shear-low moment region.

7: The maximum recorded deflection along the beam was in the beam with bottom eccentric opening in case of pure moment region while the minimum recorded deflection aiong the beam was in the beam with top eccentric opening in pure moment region

8. The failure loads decreased by ranges from $5.3 \%$ to $7.6 \%$ and from $2.3 \%$ to $6.8 \%$ for the tested beams with openings in high shear-low moment and pure moment regions respectively than that of the tested beam without opening

\section{REFERENCES.}

t. A. Badr and M. EL-Banna "Plastic behaviour of steel beams with mid-depth equispaced rectangular openings" Ain shams Univ., Eng. Bulletin, Vol.25, No.2, Aug. 1990, pp 161-181

2. Bower, John E. "Experimental stresses in wide flange beams with holes "Journal of Structural Division, ASCE, Vol. 92. No. ST 5. Proc, Paper 4945, October. 1966, pp 167-186

3- Bower, John E "Ultimate strength of beams with rectangular Holes", Journal of Structural Division, ASCE, Vol. 94, No. ST 6, June, 1968.

4. Douglos, T. R and Gambrell, Jr, S. C. (1974) "Design of beams with off-Center web openings" Journal of Struc. Division, Proc., ASCE, 100(ST6), 1189-1203

5. Redwood, R. G, and John O. McCutcheon "Beam tests with uniforced web openings" Journal of Structural Division, ASCE, Vol. 94, No. ST.1, Jan, 1968.

6- T.S.Arda, \& G.Bayramoglu "An Experimental study on butt welded steel beams with half NPI chords and rectangular openings" Instanbul Technical University Press, 1993, Instanbul, Turkey

7. "Egyptian Code of Practice for Steel Constructions and Bridges", 1989.

8. "Germany Specifications, DIN 17100, "Aligemeine Baustaelle Guetennorm", Jan. 1988, Stahlbau. 
Aansoura Engineering lournal (MEJ), Vol.20, No 3, Sept.1995 C.7

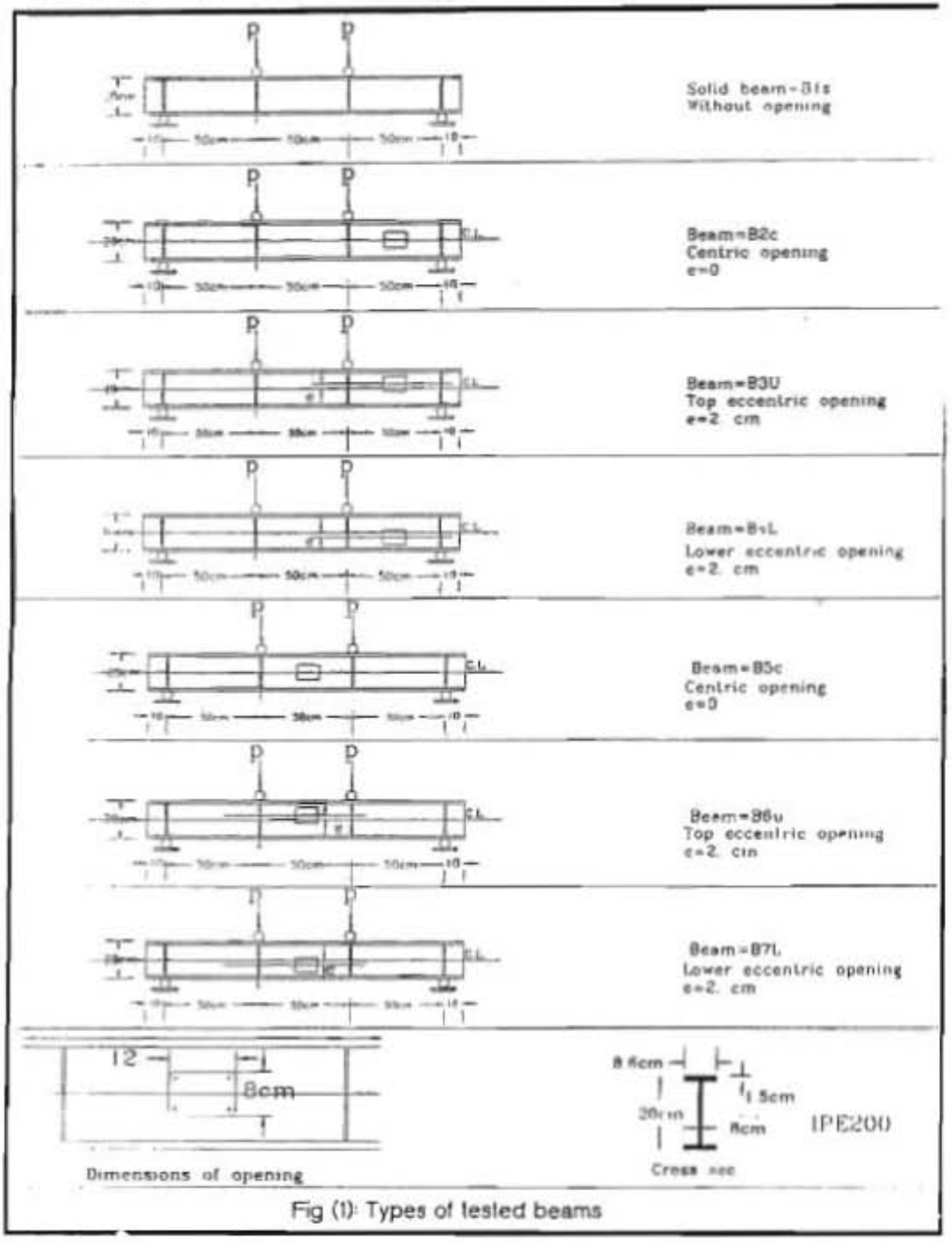


C. 8 ABD-RABOU, ABO MOSAI.I AM \& BADR

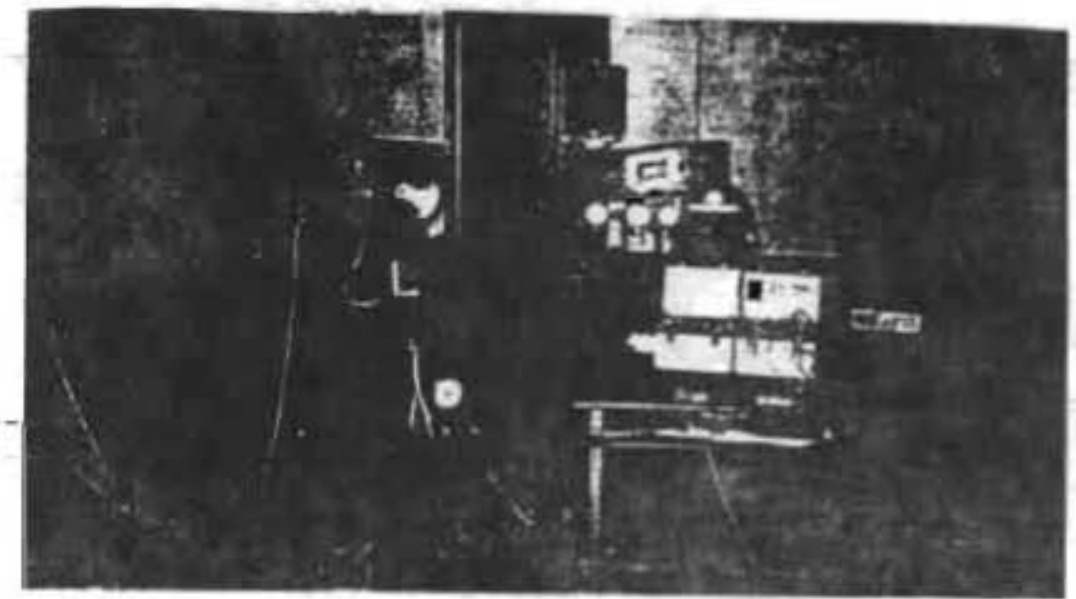

Fig.(2) : Arrangements of the experimental program.

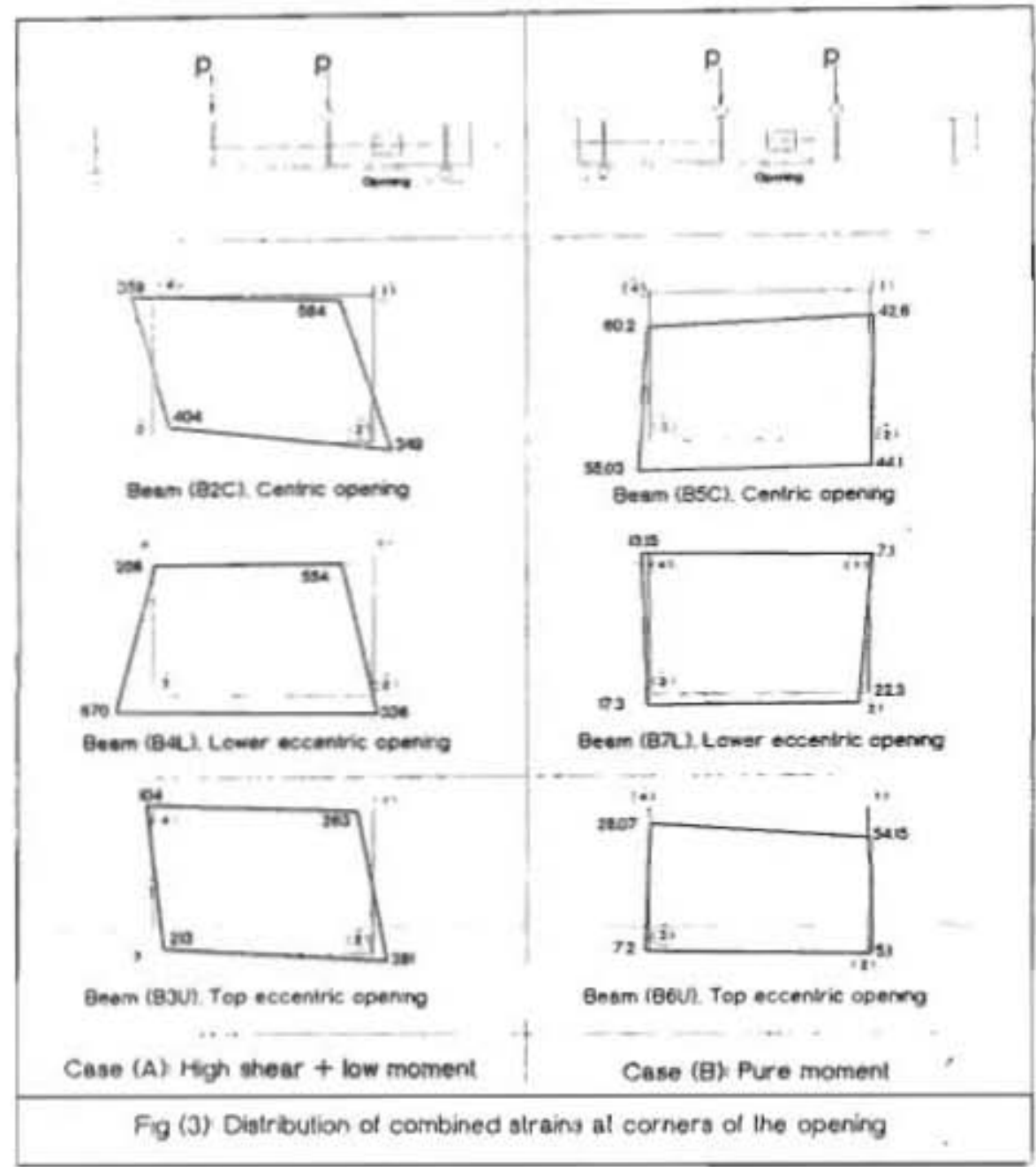


Mansoura Enyinteriay lournal (MEJ). Vei 20, No.1, Sept t905 C.
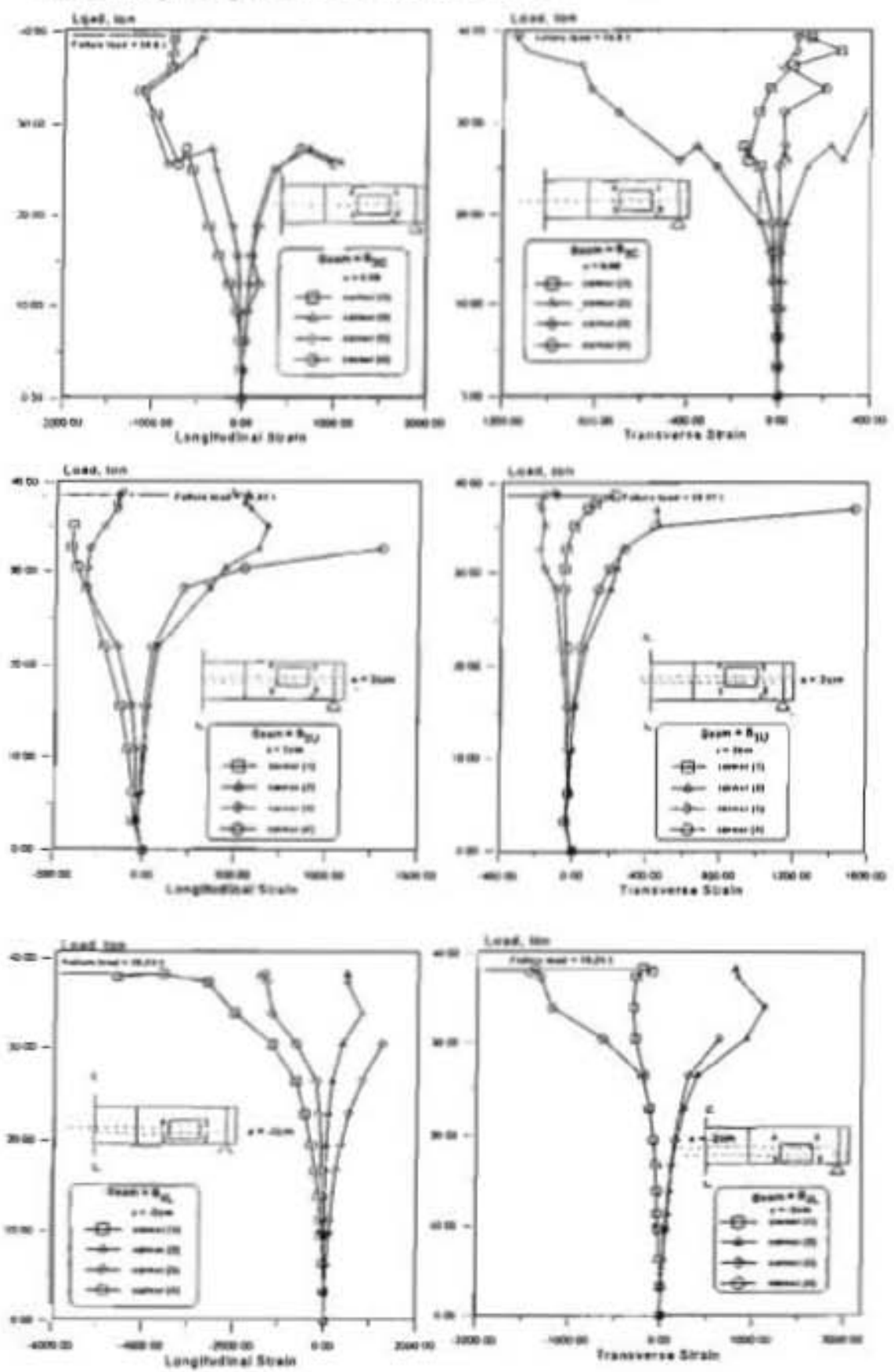

Fig.(4) : Relation berween load and strain in longitudinal and transverse directions I $10^{-3}$ at corners of the openiag $(1,2,3 \& 4)$ for beams $\left(\mathrm{B}_{2}, \mathrm{~B}_{3 \mathrm{u}} \mathrm{B}_{\mathrm{B}} \mathrm{B}\right)$ 
SIN WUU-KABUU. ABU MIUSALLAM \& BAUK
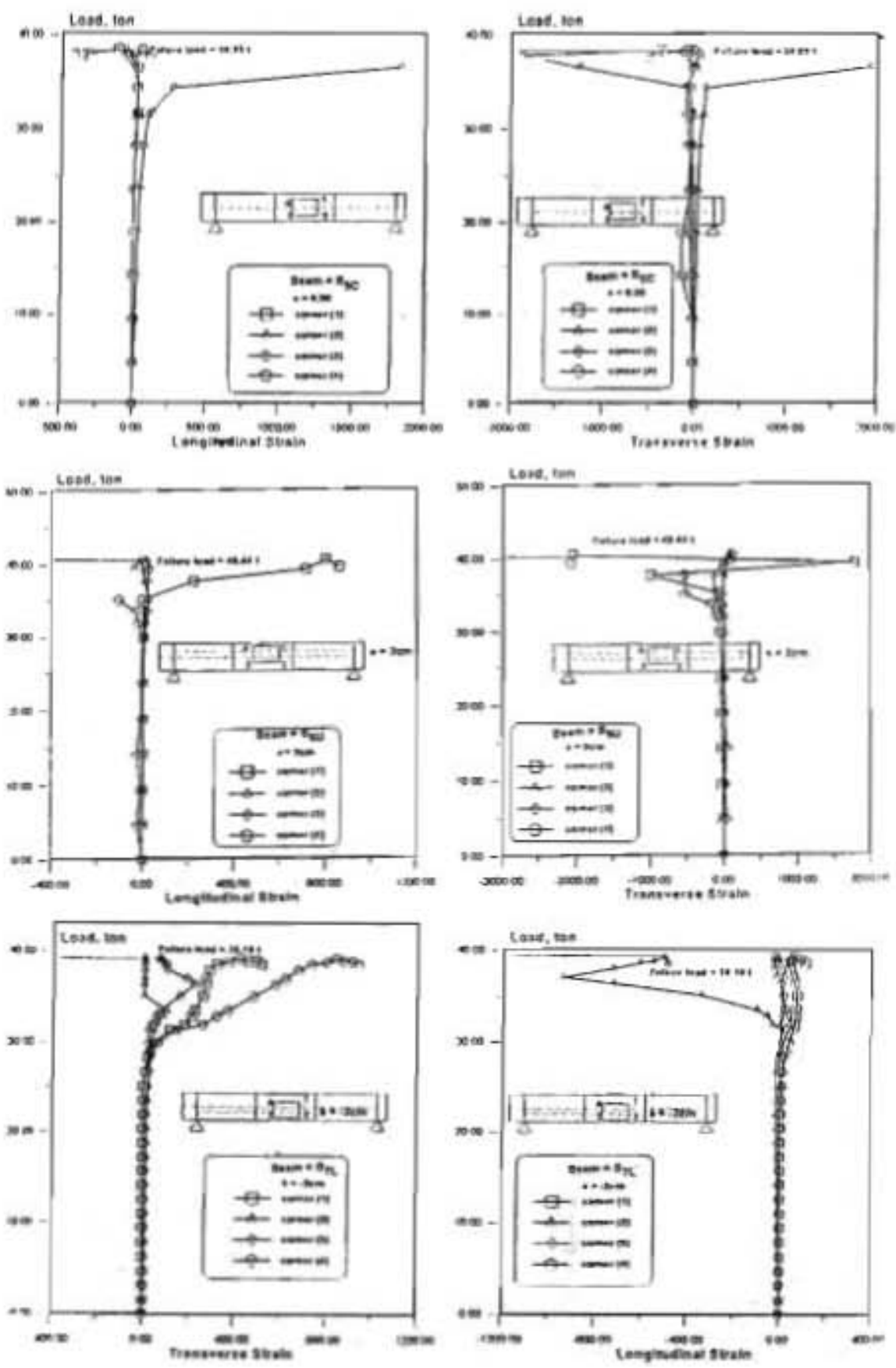

Fig.(5) : Relation between load and strain in longitudinal and transverse directions \& $10^{-3}$ st cermers of the opening $\left(1,2,3 \&_{4}\right)$ for beams $\left(\mathbf{B}_{5 \mathrm{e}} \mathrm{B}_{6}\right.$ u \&B $B_{7}$. 

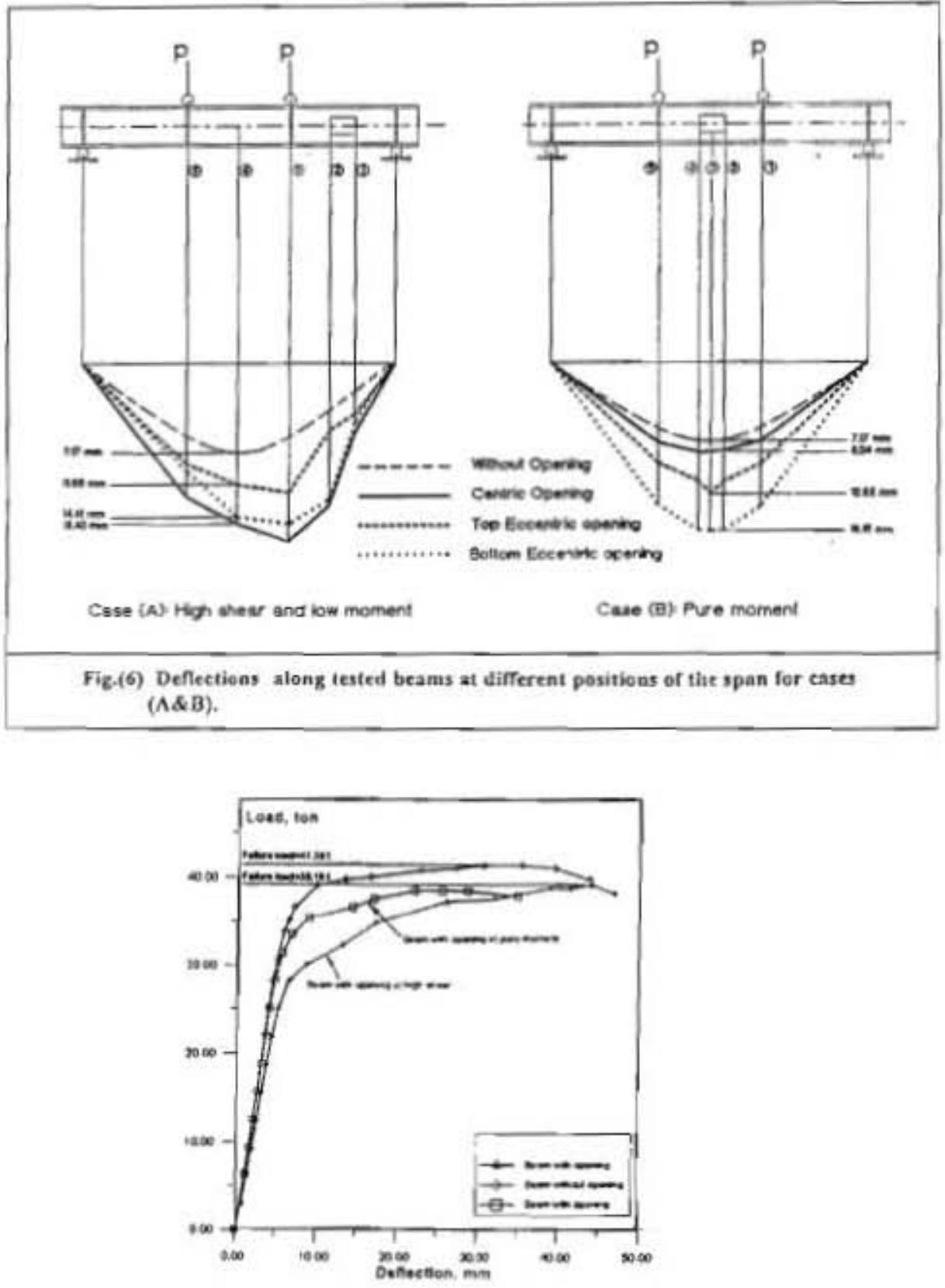

Figf7a): Relation between toad and deflection till failure for tested beams with and without opening. 
C 12 ABD-RABOU, ABO MOSALLAM \& BADR
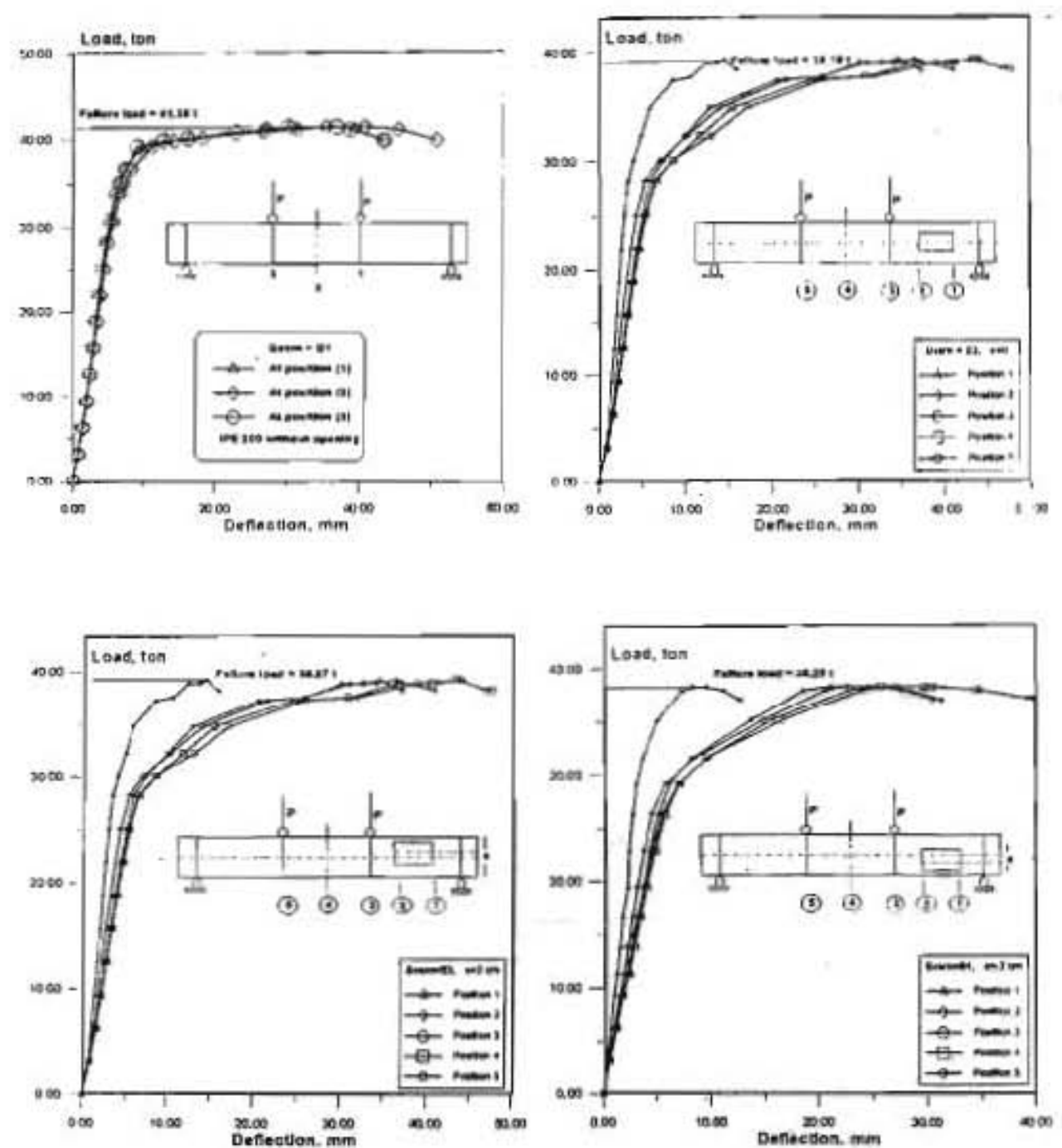

Fig.(7b): Relation between load and deflection till failure for tested beams ( $B_{15}$, $\mathrm{B}_{2} \mathrm{C}^{\mathrm{B}} \mathrm{Bu}_{\mathrm{u}}$ and $\mathrm{B}_{4} \mathrm{~L}$. 
Mansoura Engineering Journal (MEJ), Vol 20, No.3, Sept.1995 C.13
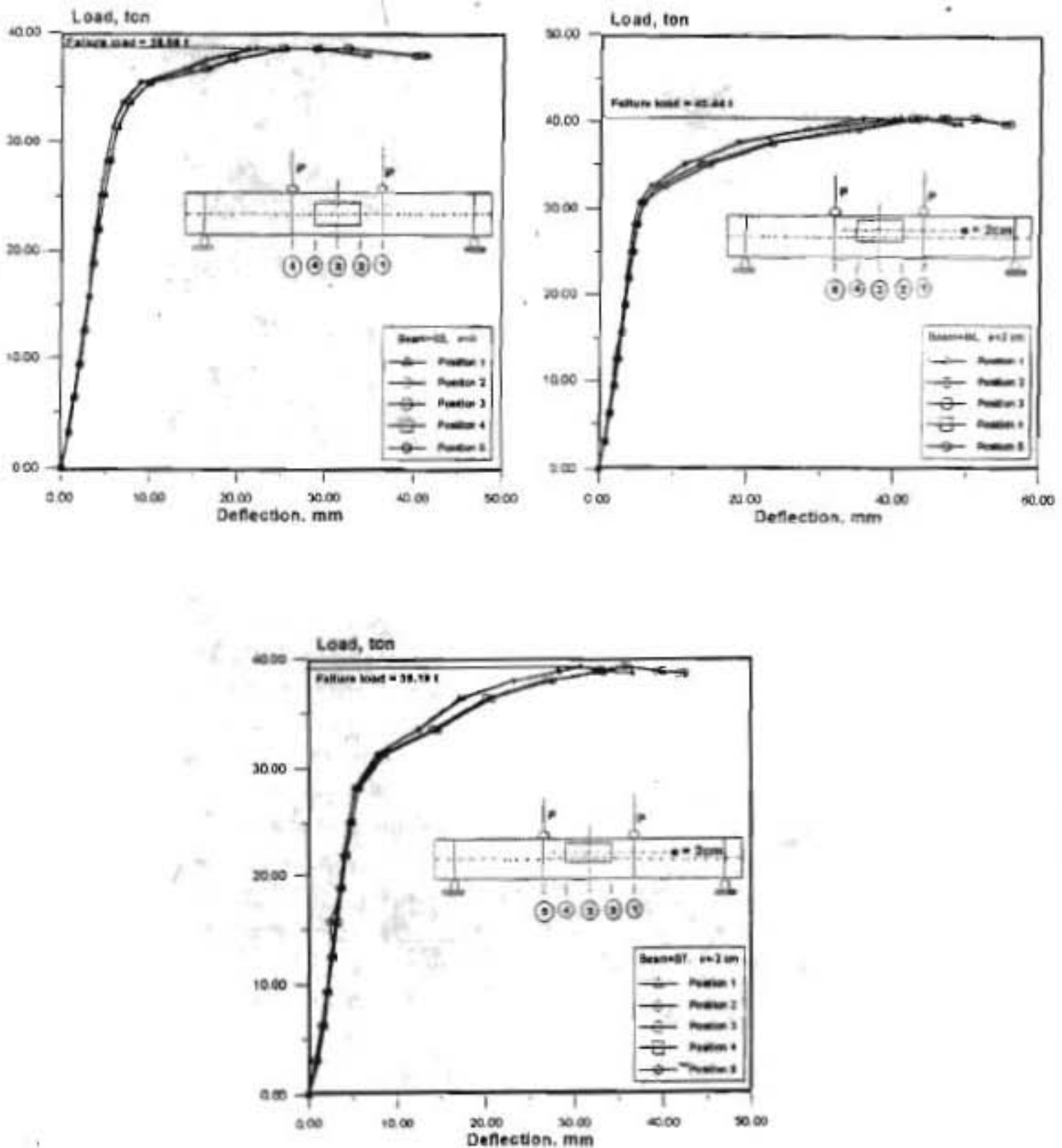

Fig.(8): Relation between load and deflection till failure for tested beams $\left(\mathrm{B}_{5 \mathrm{c}}, \mathrm{B}_{6 \mathrm{u}}\right.$ and $\mathrm{B}_{7 \mathrm{~L}}$. 
C 14 ABD-RABOU. ABO MOSALLAM \& BADR
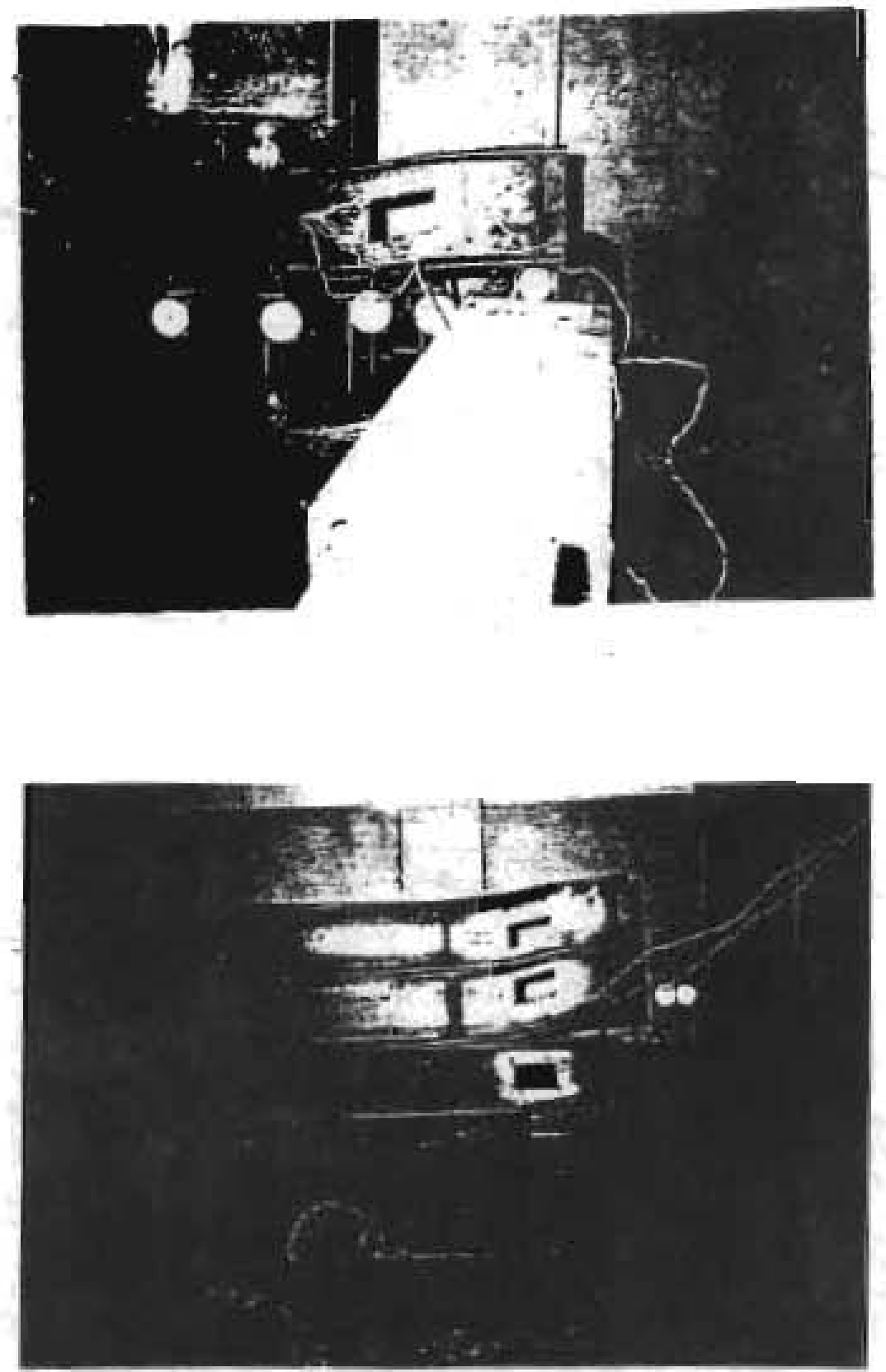

Fig.9 : Medes of Failures. 